Saudi Journal of Business and Management Studies Abbreviated Key Title: Saudi J Bus Manag Stud ISSN 2415-6663 (Print) |ISSN 2415-6671 (Online) Scholars Middle East Publishers, Dubai, United Arab Emirates Journal homepage: https://saudijournals.com

Original Research Article

\title{
Risk Perception \& Trust towards E-Commerce in Bangladesh: Logistic Regression \& Kano Model Approach
}

Mohammad Ahsan Uddin

Associate Professor, Department of Statistics, University of Dhaka, Bangladesh

DOI: $10.36348 /$ sjbms.2020.v05i12.005 $\quad$ | Received: 29.11.2020 | Accepted: 14.12.2020 | Published: 24.12.2020

*Corresponding author: Mohammad Ahsan Uddin

Abstract

E-commerce or electronic commerce indicates such an industry where business activities take place over electronic systems. This is now a rapidly growing sector in Bangladesh which is influencing local and international trade in a greater extent. As e-commerce practicing is now a very common phenomenon in our daily life, it is important to understand the key issues in building relationships with customers on the internet. Trust is supposed to be the key to these relationships. This research identifies a number of key factors related to trust and risk perception of the customers in the context of e-commerce through binary logistic regression model. Cronbach's alpha is used to test the reliability of scale used in the questionnaire. Kano model analyzes the factors that might be concerned to upgrade the satisfaction level of the customers. The findings in this research suggest that customer's trust levels and risk perception are likely to be influenced by their age, experience of using internet, internet using purpose, and market orientation. Focusing on social risk, improving responsiveness towards customers, and ensuring technological security are the factors that mostly determine the customers' satisfaction to e-commerce.

Keywords: trustworthiness, risk perception, Cronbach's alpha, binary logistic regression, Kano model.

Copyright $\odot$ (2020 The Author(s): This is an open-access article distributed under the terms of the Creative Commons Attribution 4.0 International License (CC BY-NC 4.0) which permits unrestricted use, distribution, and reproduction in any medium for non-commercial use provided the original author and source are credited.

\section{INTRODUCTION}

Internet has become an important business platform for trading, distributing, and selling products and services. In this era of internet, e-commerce has been turned out into an entirely new level $[1,2]$. Ecommerce or electronic commerce means any type of business or commercial transaction that takes place via internet [3]. It works as a central issue in the global economy for doing business in new way [4]. Standing at the heart of new distribution channel, it supports online vendor to provide product and service that are fruitful and superior in many ways to traditional channel $[5,6]$.

E-commerce is an increasingly essential area in the developing countries for enhancing economic growth and welfare [7]. For the developing countries, it provides twofold opportunities, one is it enables developing country business to take part as vendors in international market, another is it permits them to buy necessary goods and services at least possible time from the developed world [8]. For this reason, developing countries are giving much attention to adopt ecommerce in their national trade strategies. UNCTAD survey on national e-strategies finds that a significant number of developing countries have included ecommerce in their national e-strategies and targeted some sectors for the development of internet based business [9].

Internet services are now very much available in Bangladesh [10]. In recent times, e-commerce has grown vastly Worldwide as well as in Bangladesh. Many Bangladeshi organizations are trying to build physical infrastructures to develop e-commerce and mimic e-commerce model from developed countries [11]. Bangladesh Government strongly supports the development of e-commerce and also it is viewed as a national trade strategy here [12]. The present Government is aiming at making digital Bangladesh. To fulfill the dream, the Government is initiating different e-commerce programs across the country [13]. Already 
a promising start in e-commerce has been started here. For instance, mobile phone companies are using ecommerce in the form of flexi-load, bill pay services; banks are using e-commerce by online banking system, shopping malls are using it though buying and selling products through the credit card [14]. Moreover, ministry of commerce, ministry of planning, and ministry of information and communication are jointly promoting the e-commerce in Bangladesh.

Trust is an important concept to the development of business to customer (B2C) ecommerce. In fact, trust is a basic principle of every business relationship [14]. The most important longterm barrier for ascertaining the potential of internet marketing to consumers is the lack of trust of the customers, both in the honesty of the merchant's and merchant's competence to fill internet orders [15]. This study aims at addressing the key variables that affect the perception of trust and risk of the customers on ecommerce. Also, the factors that the e-commerce companies should focus on to earn customer satisfaction are also determined in this study.

\section{METHODS AND MATERIALS}

A primary dataset is collected and analyzed with a view to obtaining current information about perception of e-commerce with respect to business to consumer (B2C) e-commerce websites. The data is collected from people of different age groups from
Dhaka city. The respondents may have good experience of using internet or not. They also may or may not have former experience with e-commerce websites and businesses. The data collection is done following convenience sampling, where a sufficient questionnaire is made on this purpose. The sample, which is used for this study, is 450 people from Dhaka city, Bangladesh. Binary logistic regression analysis, a very popular statistical analysis approach, is used to analyze the trustworthiness and risk perception of the customers. If the response vector $\mathbf{Y}$ be of binary type, i.e., meaning to whether an event of interest has occurred or not, binary logistic regression is used, which takes the following functional form [16].

$$
\pi(\mathbf{x})=\frac{\mathrm{e}^{\mathbf{x}^{\prime} \boldsymbol{\beta}}}{1+\mathrm{e}^{\mathbf{x}^{\prime} \boldsymbol{\beta}}}
$$

Where $\pi(\mathbf{x})$ represents the conditional mean of $\mathbf{Y}$ given $\mathbf{x}$ i.e., $\mathrm{E}(\mathbf{Y} \mid \mathbf{x})$. The unknown parameter $\boldsymbol{\beta}$ is estimated by the method of maximum likelihood estimation $[17,18]$.

Kano model is used in this study to find out customer's needs that require to give highest priority to improve performance of e-commerce by increasing customer's satisfaction $[19,20]$. This model divides the needs of the customers into basic needs, expected needs and excitement needs and then specifies the rank of each needs within the groups [21].

\section{The Kano model}

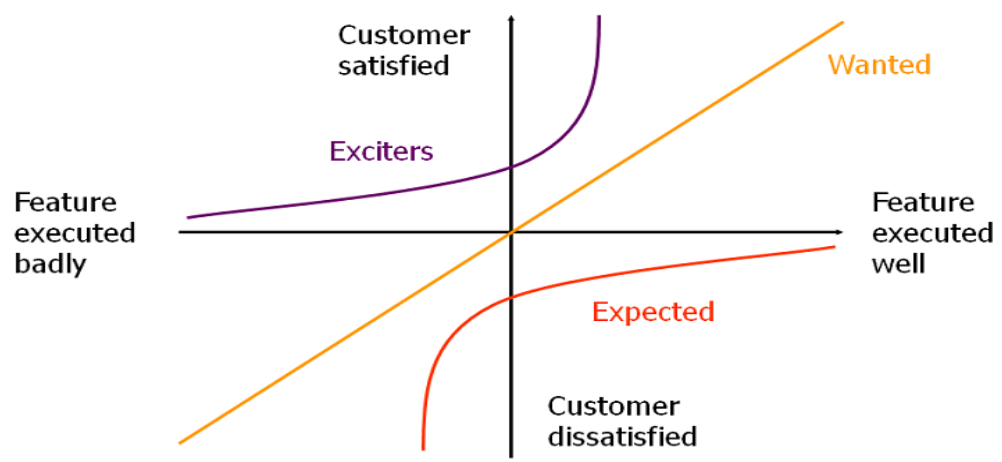

Fig-1: The Kano Model Analysis

Oftentimes, data collection on the attitudes, personalities, opinions, emotions, and descriptions involves the use of Likert scales [22, 23]. As individuals attempt to quantify constructs that cannot be measured directly promotes using multiple-item scales and summated ratings to quantify the construct(s) of interest $[24,25]$. We have devised thirty-four items to measure trust, risk perception, market orientation, technology trustworthiness and web experience. Each question used in this study was in a 5-point Likert item from "strongly disagree" to "strongly agree" categories. Cronbach's alpha is considered to be a measure of scale reliability
[26]. It is generally used when there are multiple Likert questions which form a scale and the researcher wants to determine whether the scale is reliable or not [27]. Cronbach's alpha is calculated as the squared correlation of the sample values which is obtained using a multiitem scale and their true values [28]. Mathematically:

$$
\alpha=\frac{\mathrm{k}}{\mathrm{k}-1}\left(1-\frac{\sum_{\mathrm{i}=1}^{\mathrm{k}} \sigma_{\mathrm{Y}_{\mathrm{i}}}^{2}}{\sigma_{\mathrm{X}}^{2}}\right),
$$

Where $\mathrm{k}$ is the number of items, $\sigma_{\mathrm{X}}^{2}$ is the variance of the sum of all of the items, and $\sigma_{Y_{i}}^{2}$ is the 
variance of the $\mathrm{i}^{\text {th }}$ item [22]. As it is a ratio of two variances, its theoretical value varies from zero to one. Higher values of alpha are more desirable and most of the researchers, as a rule of thumb, require a reliability of 0.70 or higher before they use an instrument [29].

\section{RESULTS AND DISCUSSIONS}

The Reliability Statistics at Table-1 provides the actual value for Cronbach's alpha. It is seen that Cronbach's alpha is 0.776, which indicates a high level of internal consistency for our scale with the data.
Table-1: Reliability statistics

\begin{tabular}{|l|l|}
\hline \multicolumn{2}{|l|}{ Reliability statistics } \\
\hline Cronbach's Alpha & Number of Items \\
\hline 0.776 & 34 \\
\hline
\end{tabular}

The final column of Table- 2 shows the values of Cronbach's alpha if the corresponding items are deleted. We can see from the values at last column that removal of any item would result in a lower Cronbach's alpha (lower than 0.776). Therefore, we would not remove these questions.

Table-2: Item-Total Statistics

\begin{tabular}{|c|c|c|c|c|}
\hline \multicolumn{5}{|c|}{ Item-Total Statistics (if corresponding item is deleted) } \\
\hline & $\begin{array}{l}\text { Scale } \\
\text { Mean }\end{array}$ & $\begin{array}{l}\text { Scale } \\
\text { Variance }\end{array}$ & Correlation* & $\begin{array}{l}\text { Cronbach's } \\
\alpha\end{array}$ \\
\hline Necessary skills and ability to carry out online transaction & 111.19 & 116.719 & 0.374 & 0.766 \\
\hline $\begin{array}{l}\text { Necessary technology knowledge to carry out online } \\
\text { transaction }\end{array}$ & 111.25 & 117.232 & 0.319 & 0.768 \\
\hline Technology obstacles should not be a major concern & 111.69 & 117.426 & 0.255 & 0.772 \\
\hline Technical failure & 111.56 & 117.050 & 0.316 & 0.768 \\
\hline Technical failure & 111.56 & 117.050 & 0.316 & 0.768 \\
\hline Predict performance by the customers & 110.94 & 119.382 & 0.263 & 0.771 \\
\hline Past and future behaviors are positively related & 110.79 & 118.341 & 0.295 & 0.770 \\
\hline When the new one is dealing, I had a pleasant experienced & 110.99 & 119.134 & 0.279 & 0.770 \\
\hline Care, concern, goodwill to their customers & 111.08 & 114.664 & 0.441 & 0.762 \\
\hline Performing the outmost of the customers benefit & 111.23 & 117.229 & 0.322 & 0.768 \\
\hline Demonstrate customers believe & 111.54 & 116.594 & 0.334 & 0.768 \\
\hline Risky when fail to meet customer expectations & 110.81 & 123.393 & 0.044 & 0.770 \\
\hline Risky when the products inferior quality & 110.80 & 120.771 & 0.181 & 0.774 \\
\hline Risky when the products may be dangerous & 111.42 & 120.617 & 0.151 & 0.776 \\
\hline Risky when the products may be available lower price & 111.01 & 121.330 & 0.133 & 0.767 \\
\hline Risky when it may cause others to think poorly & 111.66 & 119.364 & 0.209 & 0.774 \\
\hline $\begin{array}{l}\text { Risky when the products delivered may fail my personal } \\
\text { image }\end{array}$ & 111.31 & 119.452 & 0.233 & 0.772 \\
\hline $\begin{array}{l}\text { Risky when the products delivered may fail the expected } \\
\text { time }\end{array}$ & 111.11 & 120.112 & 0.194 & 0.774 \\
\hline The web sites are good at collecting customers information & 111.07 & 119.181 & 0.273 & 0.771 \\
\hline Web sites encourage customers to send their feedback & 110.86 & 118.748 & 0.296 & 0.770 \\
\hline Feeling embarrassed to send negative feedback & 111.04 & 119.176 & 0.243 & 0.772 \\
\hline Web sites review and customers opinions effectively & 111.13 & 118.538 & 0.281 & 0.770 \\
\hline Customers opinion can reach the relevant department & 111.23 & 117.655 & 0.315 & 0.769 \\
\hline Customers opinion can easily be lost & 111.19 & 120.675 & 0.174 & 0.775 \\
\hline Customers opinion can influence the way of website & 110.76 & 119.431 & 0.283 & 0.770 \\
\hline Receiving a timely response & 111.10 & 119.241 & 0.268 & 0.771 \\
\hline Purchasing is solved effectively and satisfactorily & 111.26 & 117.631 & 0.318 & 0.768 \\
\hline Web sites value customers opinion & 111.09 & 119.116 & 0.280 & 0.770 \\
\hline Allowing customers contribution to the sites & 111.19 & 117.595 & 0.344 & 0.767 \\
\hline $\begin{array}{l}\text { Transactions and deliveries work out quite smoothly by the } \\
\text { joint effort }\end{array}$ & 111.01 & 119.092 & 0.321 & 0.769 \\
\hline Finding out mistake during transaction & 111.10 & 117.818 & 0.323 & 0.768 \\
\hline Conflicting information on the different pages & 110.89 & 120.456 & 0.201 & 0.774 \\
\hline Capable of processing a large number of transactions & 111.24 & 114.915 & 0.425 & 0.763 \\
\hline Technologies are effective keeping the accurate data & 111.12 & 117.914 & 0.329 & 0.768 \\
\hline Getting access to the data without permission & 110.53 & 121.635 & 0.121 & 0.775 \\
\hline
\end{tabular}

\footnotetext{
*Corrected Item-Total Correlation
} 
Table-3 represents the binary logistic regression model results that investigates the factors behind the trustworthiness of the customers on ecommerce. The result finds the variables age, experienced of using internet, internet using purpose, and market orientation as significant, while education status, payment system, and technology are insignificant at 5\% level of significance. Age has a significant association ( $\mathrm{p}$-value 0.044 ) with trust in online business. The odds of having trust is increased by $(1.584-1) * 100 \%$ or $58.4 \%$ for one unit increase in age, keeping all other covariates at fixed level. The respondents who are experienced of using internet have significantly $51.5 \%$ less odds of having trust in online business compared to those who are inexperienced having $p$-value 0.005 . For the variable internet using purpose, the respondents using internet for educational purpose, online banking, and online game have significantly 2.469, 2.775, and 1.918 times odds, respectively, of having trust on e-commerce compared to those who belong to others category with respective p-value 0.098, 0.035, and 0.095. Market orientation significantly increases the odds of having trust on ecommerce by 5.705 times with p-value less than 0.001 .

Table-3: Binary logistic regression model estimates of the selected covariates for having trust on e-commerce along with standard error (SE), odds ratio (OR), and p-value

\begin{tabular}{|c|c|c|c|c|}
\hline Covariates & Coefficient & SE & OR & p-value \\
\hline Constant & -5.366 & 1.728 & 0.004 & 0.001 \\
\hline Age & 0.460 & 0.249 & 1.584 & 0.044 \\
\hline \multicolumn{5}{|l|}{ Education status } \\
\hline Secondary & 0.669 & 1.416 & 1.952 & 0.636 \\
\hline Higher secondary & 1.037 & 1.419 & 2.820 & 0.465 \\
\hline Graduate & 0.683 & 1.506 & 1.980 & 0.650 \\
\hline Higher & 0.503 & 2.278 & 1.654 & 0.825 \\
\hline Primary & - & - & - & - \\
\hline \multicolumn{5}{|c|}{ Experienced of using internet } \\
\hline Agree & -0.722 & 0.446 & 0.485 & 0.005 \\
\hline Disagree & - & - & - & - \\
\hline \multicolumn{5}{|c|}{ Internet using purpose } \\
\hline Entertainment & -0.023 & 0.501 & 0.976 & 0.961 \\
\hline Educational purpose & 0.903 & 0.547 & 2.469 & 0.098 \\
\hline Shopping & -0.245 & 0.358 & 0.782 & 0.494 \\
\hline Information search & -0.388 & 0.541 & 0.678 & 0.473 \\
\hline Social networking & -0.203 & 0.451 & 0.815 & 0.652 \\
\hline Online banking & 1.020 & 0.486 & 2.775 & 0.035 \\
\hline Online game & 0.651 & 0.390 & 1.918 & 0.095 \\
\hline Others & - & - & - & - \\
\hline \multicolumn{5}{|l|}{ Payment system } \\
\hline Visa & 0.049 & 0.504 & 1.050 & 0.922 \\
\hline Amex & -1.375 & 0.943 & 0.252 & 0.145 \\
\hline Paypal & -0.298 & 1.505 & 0.742 & 0.843 \\
\hline Amazon payments & -1.573 & 1.186 & 0.207 & 0.184 \\
\hline Master card & -0.062 & 0.551 & 0.938 & 0.909 \\
\hline bkash & 1.047 & 0.405 & 2.851 & 0.119 \\
\hline Rocket DBBL & -0.064 & 0.559 & 0.937 & 0.907 \\
\hline Cash on delivery & - & - & - & - \\
\hline \multicolumn{5}{|l|}{ Market orientation } \\
\hline Agree & 1.741 & 0.363 & 5.705 & $<0.001$ \\
\hline Disagree & - & - & - & - \\
\hline \multicolumn{5}{|l|}{ Technology } \\
\hline Agree & 1.244 & 0.388 & 3.470 & 0.211 \\
\hline Disagree & - & - & - & - \\
\hline
\end{tabular}

Risk perception of the customers on ecommerce is analyzed through binary logistic regression and the result is presented at Table-4. According to the table, the variables experienced of using internet, internet using purpose, and market orientation are significant factors of risk perception, while age, education status, payment system, and technology are found insignificant at 5\% significance level. The variable experienced of using internet is significant at $5 \%$ level of significance (p-value .017). An individual who is experienced of using internet has $(1-0.407) * 100 \%$ or $59.3 \%$ lower odds of having risk perception on e-commerce compared to an individual who is not experienced of using internet, keeping all 
other variables at a fixed level. For the variable internet using purpose, the individuals who use internet for entertainment and the respondents who use internet for social networking have significantly $(1-0.439) * 100 \%$ or $56.1 \%$ lower odds and 3.343 times odds of having risk perception, respectively, compared to the individuals who belongs to the others category having respective $\mathrm{p}$ value 0.077 and 0.003 . Market orientation significantly increases the odds of having risk perception on $\mathrm{e}$ commerce by 2.112 times with p-value 0.019 .

Table-4: Binary logistic regression model estimates of the selected covariates for risk perception on e-commerce along with standard error (SE), odds ratio (OR), and p-value

\begin{tabular}{|l|l|l|l|l|}
\hline Covariates & Coefficient & SE & OR & p-value \\
\hline Constant & -16.527 & 1313.917 & $<0.001$ & 0.989 \\
\hline Age & 0.114 & 0.211 & 1.121 & 0.587 \\
\hline Education status & & & & \\
\hline Secondary & 15.678 & 1313.917 & $>50.000$ & 0.990 \\
\hline Higher secondary & 15.565 & 1313.917 & $>50.000$ & 0.990 \\
\hline Graduate & 15.038 & 1313.917 & $>50.000$ & 0.990 \\
\hline Higher & -0.726 & 1891.722 & 0.483 & 0.999 \\
\hline Primary & - & - & - & - \\
\hline Experienced of using internet & & & & \\
\hline Agree & -0.896 & 0.377 & 0.407 & 0.017 \\
\hline Disagree & - & - & - & - \\
\hline Internet using purpose & & & & \\
\hline Entertainment & -0.821 & 0.466 & 0.439 & 0.077 \\
\hline Educational purpose & 0.135 & 0.461 & 1.145 & 0.769 \\
\hline Shopping & -0.229 & 0.312 & 0.795 & 0.463 \\
\hline Information search & 0.199 & 0.473 & 1.220 & 0.673 \\
\hline Social networking & 1.207 & 0.409 & 3.343 & 0.003 \\
\hline Online banking & 0.160 & 0.425 & 1.173 & 0.706 \\
\hline Online game & -0.188 & 0.339 & 0.828 & 0.578 \\
\hline Others & - & - & - & - \\
\hline Payment system & & & & \\
\hline Visa & -1.989 & 0.636 & 0.136 & 0.121 \\
\hline Amex & 1.342 & 0.801 & 3.829 & 0.193 \\
\hline Paypal & 0.727 & 1.359 & 2.069 & 0.592 \\
\hline Amazon payments & 0.091 & 1.011 & 1.095 & 0.927 \\
\hline Master card & -0.719 & 0.609 & 0.486 & 0.237 \\
\hline bkash & -4.225 & -458.591 & 1.717 & 0.121 \\
\hline Rocket DBBL & 0.495 & 0.508 & 1.641 & 0.329 \\
\hline Cash on delivery & - & - & - & - \\
\hline Market orientation & & & & \\
\hline Agree & 0.747 & 0.321 & 2.112 & 0.019 \\
\hline Disagree & - & - & - & - \\
\hline Technology & & & & \\
\hline Agree & -0.222 & 0.334 & 0.801 & 0.506 \\
\hline Disagree & - & - & - & - \\
\hline & & & & \\
\hline & & & & \\
\hline
\end{tabular}

On the construction of Kano questionnaire, for each product feature, a pair of questions is formulated to which the customer can answer in one of five different ways [30]. The first question is about the reaction of the customer if the product ensures certain features (functional form of the question) and the second question is about the reaction if the product does not met the features (dysfunctional form of the question) [31].

Table-5: Functional and dysfunctional question in questionnaire

\begin{tabular}{|l|l|l|}
\hline $\begin{array}{l}\text { Functional form of the } \\
\text { question }\end{array}$ & $\begin{array}{l}\text { How much you agree with the statement "Most commercial websites } \\
\text { have the necessary skills and ability to carry out online transaction." }\end{array}$ & $\begin{array}{l}\text { Strongly agree } \\
\text { Agree } \\
\text { Neutral } \\
\text { Disagree } \\
\text { Strongly disagree }\end{array}$ \\
\hline $\begin{array}{l}\text { Dysfunctional form of } \\
\text { the question }\end{array}$ & $\begin{array}{l}\text { How much you agree with the statement "Most commercial websites do } \\
\text { not have the necessary skills and ability to carry out online transaction" }\end{array}$ & $\begin{array}{l}\text { Strongly agree } \\
\text { Agree } \\
\text { Neutral } \\
\text { Disagree } \\
\text { Strongly disagree }\end{array}$ \\
\hline
\end{tabular}


By combining the two answers the product features can be classified as given in Table 6. From the Kano matrix at Table 6, category $\mathrm{A}$ indicates attractive customer requirement from the customer's viewpoint. If the attractive requirements exist, it's better for the companies but if they don't exist, it doesn't imply that the customers become dissatisfied. Category $\mathrm{O}$ highlights the one-dimensional requirements, which means that their presence satisfies the customers, moreover, the more intense, the higher the satisfaction. Category I means that customers are indifferent to what feature the product has. So, these features don't affect the degree of client satisfaction. Questionable result is expressed by category Q. Usually, the answers hardly fall into this category. Questionable scores imply that the question was phrased wrongly or the respondent misunderstood the question or a wrong answer is crossed out by mistake. Category $\mathrm{R}$ implies this product feature is not wanted by the customer but he may expect the reverse. Category $M$ stands for must be given requirements. The clients will surely be dissatisfied without them.

Table-6: KANO matrix

\begin{tabular}{|c|c|c|c|c|c|c|}
\hline \multirow{2}{*}{\multicolumn{2}{|c|}{ Customers requirement }} & \multicolumn{5}{|c|}{ Dysfunctional Question's rating (Negative Question) } \\
\hline & & Like & Must be & Neutral & Live with & Dislike \\
\hline \multirow{5}{*}{$\begin{array}{l}\text { Functional Questions Rating } \\
\text { (Positive Question) }\end{array}$} & Like & Q & A & A & A & $\mathrm{O}$ \\
\hline & Must be & $\mathrm{R}$ & $\mathrm{I}$ & I & $\mathrm{I}$ & M \\
\hline & Neutral & $\mathrm{R}$ & $\mathrm{I}$ & $\mathrm{I}$ & $\mathrm{I}$ & $\mathrm{M}$ \\
\hline & Live with & $\mathrm{R}$ & $\mathrm{I}$ & $\mathrm{I}$ & $\mathrm{I}$ & M \\
\hline & Dislike & $\mathrm{R}$ & $\mathrm{R}$ & $\mathrm{R}$ & $\mathrm{R}$ & Q \\
\hline
\end{tabular}

Table-7: Hierarchical table of customer's need

\begin{tabular}{|c|c|c|}
\hline \multirow{14}{*}{ Customer needs } & \multirow[t]{3}{*}{ Trust } & Competence \\
\hline & & Predictability \\
\hline & & Good will \\
\hline & \multirow{5}{*}{ Risk Perception } & Perception Risk \\
\hline & & Financial Risk \\
\hline & & Social Risk \\
\hline & & Psychological Risk \\
\hline & & Time Risk \\
\hline & \multirow{4}{*}{ Market Orientation } & Information Generation \\
\hline & & Information Dissemination \\
\hline & & Responsiveness \\
\hline & & Coordination Mechanism \\
\hline & \multirow[t]{2}{*}{ Technology Trustworthiness } & Reliability \\
\hline & & Security \\
\hline
\end{tabular}

Table-8 analyzes customers' needs and compares the priorities which might be fulfilled to satisfy customers. In the group of one dimensional needs $(\mathrm{O})$, social risk gained $35.8 \%$ frequency under risk perception. It confirms that in order to keep customers happy, e-commerce must give first priority to social risk. In the group of must be given needs $(\mathrm{M})$, responsiveness gained $67.1 \%$ frequency which is higher than any other needs in this group. So, it is necessary to improve responsiveness towards customer in order to keep them satisfied. Security, under technology trustworthiness, carries $32.2 \%$ frequency in the attractive needs group (A). It will lead to customers' satisfaction high but it may not be the reason for their disappointment because it is in attractive need group. Finally, in the group of indifferent needs (I), customers are indifferent about competence (44\%). The reverse $(\mathrm{R})$ and questionable $(\mathrm{Q})$ categories are found inactive on the dataset as the frequencies obtained in the categories are very low. 
Table-8: Identification of product and prioritizing requirements

\begin{tabular}{|c|c|c|c|c|c|c|c|c|}
\hline & Customers Need & O & $\mathbf{M}$ & A & I & $\mathbf{R}$ & $\mathbf{Q}$ & Cat \\
\hline \multirow[t]{2}{*}{ Trust } & Predictability & 0.016 & 0.607 & 0.153 & 0.224 & 0.0 & 0.0 & $\mathrm{M}$ \\
\hline & Good will & $\begin{array}{l}0.082 \\
8.2 \%\end{array}$ & $\begin{array}{l}0.433 \\
43.3 \%\end{array}$ & $\begin{array}{l}0.084 \\
8.4 \%\end{array}$ & $\begin{array}{l}2.470 \\
0.396 \\
39.6 \%\end{array}$ & $\begin{array}{l}0.0 \\
0 \%\end{array}$ & $\begin{array}{l}0.004 \\
0.4 \%\end{array}$ & $\mathrm{M}$ \\
\hline \multirow{5}{*}{ Risk Perception } & Perception Risk & $\begin{array}{l}0.06 \\
6 \%\end{array}$ & $\begin{array}{l}0.558 \\
55.8 \%\end{array}$ & $\begin{array}{l}0.144 \\
14.4 \%\end{array}$ & $\begin{array}{l}0.238 \\
32.8 \%\end{array}$ & $\begin{array}{l}0.0 \\
0 \%\end{array}$ & $\begin{array}{l}0.0 \\
0 \%\end{array}$ & $\mathrm{M}$ \\
\hline & Financial Risk & $\begin{array}{l}0.147 \\
14.7 \%\end{array}$ & $\begin{array}{l}0.46 \\
46.0 \%\end{array}$ & $\begin{array}{l}0118 \\
118 \%\end{array}$ & $\begin{array}{l}0.242 \\
24.2 \%\end{array}$ & $\begin{array}{l}0.0 \\
0 \%\end{array}$ & $\begin{array}{l}0.033 \\
3.3 \%\end{array}$ & $\mathrm{M}$ \\
\hline & Social Risk & $\begin{array}{l}0.358 \\
358 \%\end{array}$ & 0.289 & 0.033 & 0.238 & 0.0 & 0.082 & $\mathrm{O}$ \\
\hline & Psychological Risk & $\begin{array}{l}0.233 \\
23.3 \%\end{array}$ & $\begin{array}{l}0.358 \\
35.8 \%\end{array}$ & $\begin{array}{l}0.058 \\
5.8 \%\end{array}$ & $\begin{array}{l}0.322 \\
32.2 \%\end{array}$ & $\begin{array}{l}0.0 \\
0 \%\end{array}$ & $\begin{array}{l}0.029 \\
2.9 \%\end{array}$ & $\mathrm{M}$ \\
\hline & Time Risk & 0.204 & $\begin{array}{l}0.473 \\
47.3 \%\end{array}$ & $\begin{array}{l}0.082 \\
82 \%\end{array}$ & 0.218 & 0.0 & 0.022 & $\mathrm{M}$ \\
\hline \multirow{4}{*}{ Market Orientation } & Information Generation & $\begin{array}{l}0.009 \\
09 \%\end{array}$ & $\begin{array}{l}0.624 \\
62.4 \%\end{array}$ & $\begin{array}{l}0.096 \\
9.6 \%\end{array}$ & $\begin{array}{l}0.271 \\
27.1 \%\end{array}$ & $\begin{array}{l}0.0 \\
0 \%\end{array}$ & $\begin{array}{l}0.0 \\
0 \%\end{array}$ & $\mathrm{M}$ \\
\hline & Information Dissemination & 0.02 & 0.518 & 0.062 & 0.40 & 0.0 & 0.0 & $\mathrm{M}$ \\
\hline & Responsiveness & 0.007 & 0.671 & 0.08 & 0.242 & 0.0 & 0.0 & M \\
\hline & Coordination Mechanism & $\begin{array}{l}0.007 \\
0 . \%\end{array}$ & $\begin{array}{l}0.607 \\
607 \%\end{array}$ & $\begin{array}{l}0.109 \\
10.9 \%\end{array}$ & $\begin{array}{l}0.278 \\
278 \%\end{array}$ & $\begin{array}{l}0.0 \\
0 \%\end{array}$ & $\begin{array}{l}0.0 \\
0 \%\end{array}$ & $\mathrm{M}$ \\
\hline \multirow{2}{*}{$\begin{array}{l}\text { Technology } \\
\text { Trustworthiness }\end{array}$} & Reliability & $\begin{array}{l}0.091 \\
9.1 \%\end{array}$ & $\begin{array}{l}0.418 \\
41.8 \%\end{array}$ & $\begin{array}{l}0.084 \\
8.4 \%\end{array}$ & $\begin{array}{l}0.402 \\
40.2 \%\end{array}$ & $\begin{array}{l}0.0 \\
0 \%\end{array}$ & $\begin{array}{l}0.004 \\
0.4 \%\end{array}$ & $\mathrm{M}$ \\
\hline & Security & $\begin{array}{l}0.056 \\
5.6 \%\end{array}$ & $\begin{array}{l}0.422 \\
42.2 \%\end{array}$ & $\begin{array}{l}0.322 \\
32.2 \%\end{array}$ & $\begin{array}{l}0.176 \\
17.6 \%\end{array}$ & $\begin{array}{l}0.0 \\
0 \%\end{array}$ & $\begin{array}{l}0.024 \\
2.4 \%\end{array}$ & $\mathrm{M}$ \\
\hline
\end{tabular}

The customer satisfaction coefficient (CScoefficient) presented at Table- 9 is an indication to the degree to which customer satisfaction rises if a product requirement is fulfilled or the degree to which customer satisfaction falls if a product requirement is not fulfilled. It is important to know the average impact of a product or service requirement on the overall satisfaction of all customers. The positive CS coefficient varies from 0 to 1 . Values closer to 1 means high effect on customer satisfaction. A positive CScoefficient closer to 0 implies that it has a very little effect. Moreover, the negative CS-coefficient must also be taken into consideration. Values closer to -1 means the effect on client dissatisfaction is high if the product feature is not met. A value closer to 0 signifies that this feature causes no dissatisfaction if it is not fulfilled.

Table-9: Computation result of CS-coefficient for customer's need

\begin{tabular}{|c|c|c|c|c|}
\hline & \multirow[b]{2}{*}{ Customers Need } & \multicolumn{3}{|c|}{ Extent of satisfaction and dissatisfaction CS-coefficient } \\
\hline & & Category & $\begin{array}{l}\text { Satisfaction } \\
(\mathrm{A}+\mathrm{O}) /(\mathrm{A}+\mathrm{O}+\mathrm{M}+\mathrm{I})\end{array}$ & $\begin{array}{l}\text { Dissatisfaction } \\
(\mathrm{O}+\mathrm{M}) /\left(-1^{*}(\mathrm{~A}+\mathrm{O}+\mathrm{M}+\mathrm{I})\right)\end{array}$ \\
\hline \multirow{3}{*}{ Trust } & Competence & $\mathbf{I}$ & 0.150 & -0.496 \\
\hline & Predictability & $\mathbf{M}$ & 0.170 & -0.620 \\
\hline & Good will & $\mathbf{M}$ & 0.162 & -0.517 \\
\hline \multirow{5}{*}{ Risk Perception } & Perception Risk & $\mathbf{M}$ & 0.202 & -0.617 \\
\hline & Financial Risk & $\mathbf{M}$ & 0.274 & -0.627 \\
\hline & Social Risk & $\mathbf{O}$ & 0.425 & -0.699 \\
\hline & Psychological Risk & $\mathbf{M}$ & 0.302 & -0.605 \\
\hline & Time Risk & $\mathbf{M}$ & 0.290 & -0.690 \\
\hline \multirow{4}{*}{$\begin{array}{l}\text { Market } \\
\text { Orientation }\end{array}$} & Information Generation & $\mathbf{M}$ & 0.105 & -0.631 \\
\hline & Information Dissemination & $\mathbf{M}$ & 0.082 & -0.538 \\
\hline & Responsiveness & $\mathbf{M}$ & 0.087 & -0.678 \\
\hline & Coordination Mechanism & $\mathbf{M}$ & 0.115 & -0.613 \\
\hline \multirow[t]{2}{*}{ Technology Trustworthiness } & Reliability & $\mathbf{M}$ & 0.175 & -0.511 \\
\hline & Security & $\mathbf{M}$ & 0.384 & -0.485 \\
\hline
\end{tabular}


It is found from Table-9 that the CS-coefficient for satisfaction is highest for social risk (0.425) which suggests the e-commerce companies to focus on the social risk of the customers to make them satisfied. The security issue for technology trustworthiness is also very important to earn customer satisfaction as it gets second highest CS-coefficient score (0.384). Psychological risk (CS-coefficient 0.302) of the customers plays another vital role in the satisfaction issue. Rest of the factors are not so concerning as they have too low scores to consider. On the other hand, the CS-coefficient for dissatisfaction is high for predictability, perception risk, financial risk, social risk, psychological risk, time risk, information generation, responsiveness, and coordination mechanism. Without confirmation of these factors, the customers will often be dissatisfied.

\section{CONCLUSION \& IMPLICATIONS}

This study is about drawing conclusion on major factors related to trust and risk perception of customers towards B2C e-commerce companies by using various statistical analysis approaches. The obtained results will help to improve e-commerce performance by deciding which criteria should be given more priority within time and money constraint. This study involves binary logistic regression model to investigate the potential factors of trustworthiness and risk perception of the customers on e-commerce. The study finds that the trust on e-commerce significantly increases with the increase in age. A research is found in the literature that also shows that trust on ecommerce is influenced by age factor [32]. Internet using experience has negative relationship with having trust and having risk perception on e-commerce. A previous work finds significant association between internet using experience and trust on e-commerce [33]. The more experienced a person is in using internet, the less trust he/she has on e-commerce. Again, the experienced internet users have less risk perception on e-commerce. That is, the experienced internet users show less trust on online business, as well as they are not much worried about the risks from e-commerce. The respondents who usually use internet for educational purpose, online banking, and online game have comparatively higher chance to keep faith on ecommerce. Different internet using purposes also have significant relationship with risk perception. The respondents using internet for entertainment feel lower risk, while the respondents using internet only for social networking feel higher risk on e-commerce.

Market orientation also plays important role to increase both trust and risk perception on e-commerce. However, building trust in e-commerce may not be succeed by any individual website [1]. Rather, it can be gained at group level. Consumers first have to decide whether to purchase from online or not before deciding to purchase from which website. So, they will have to evaluate the trustworthiness towards e-commerce as a whole, before going to evaluate the possibility of any individual website. According to the Kano model findings, social risk should be given the first priority to satisfy the customers. To improve responsiveness towards customers is very important since it is found as the must be given needs. The result shows that the feature 'security confirmation', under technology trustworthiness, attracts the clients. The model finds that the respondents are indifferent about competence of the e-commerce companies. It is evident from the CScoefficients that safety confirmation on social risk, security, and psychological risk increases the satisfaction of the customers. Meanwhile, the customers are dissatisfied if they feel lacking in the factors like predictability, perception risk, financial risk, social risk, psychological risk, time risk, information generation, responsiveness, and coordination mechanism.

\section{REFERENCES}

1. Corbitt, B. J., Thanasankit, T., \& Yi, H. (2003). Trust and e-commerce: a study of consumer perceptions. Electronic commerce research and applications, 2(3), 203-215.

2. Barnes, S. J., \& Vidgen, R. T. (2002). An integrative approach to the assessment of ecommerce quality. J. Electron. Commerce Res., 3(3), 114-127.

3. Barnes, S. J., \& Vidgen, R. T. (2002). An integrative approach to the assessment of ecommerce quality. J. Electron. Commerce Res., 3(3), 114-127.

4. Vladimir, Z. (1996). Electronic commerce: structures and issues. International journal of electronic commerce, 1(1), 3-23.

5. Lee, J. N., Pi, S. M., Kwok, R. C. W., \& Huynh, M. $\mathrm{Q}$. (2003). The contribution of commitment value in Internet commerce: An empirical investigation. Journal of the Association for Information systems, 4(1), 2.

6. Gloor, P. (2012). Making the e-business transformation. Springer Science \& Business Media.

7. Männistö, L. (1999). Electronic commerce in Asia. Asia and the Future of the World Economic System, March, 1-13.

8. Hoque, M. R., Ali, M. A., \& Mahfuz, M. A. (2015). An Empirical Investigation on the adoption of eCommerce in Bangladesh. Asia Pacific Journal of Information Systems, 25(1), 1-24.

9. Secretariat, U, editor. (2002). E-commerce and development report 2001. United Nations Conference on Trade and Development.

10. Alam, M. J. (2012). E-commerce: benefits in trade \& commerce, Bangladesh. International Journal of Managment, IT and Engineering, 2(8), 571-585.

11. Hossain, M. A., Ali, M. A., Kibria, M. G., \& Bhuiyan, M. N. (2013). A survey of E-commerce of Bangladesh. International Journal of Science and Research, 2(2), 150-158. 
12. Hossan, C. G., Habib, M. W., \& Kushchu, I. (2006). Success and Failure Factors for eGovernment projects implementation in developing countries: A study on the perception of government officials of Bangladesh. In Proceedings of the 2nd European Conference on Mobile Government, Mobile Government Consortium International (pp. 136-151).

13. Hossain, N. (2000). E-commerce in Bangladesh: Status, potential and constraints. Institutional Reform and the Informal Sector, University of Maryland, College Park.

14. Hart, P., \& Saunders, C. (1997). Power and trust: Critical factors in the adoption and use of electronic data interchange. Organization science, 8(1), 23-42.

15. Keen, P. G. (1997). Are you ready for "Trust" Economy. ComputerWorld, 31(16), 80.

16. Sarkar, S. K., \& Midi, H. (2010). Importance of assessing the model adequacy of binary logistic regression. Journal of Applied Sciences, 10(6), 479-486.

17. Myung, I. J. (2003). Tutorial on maximum likelihood estimation. Journal of mathematical Psychology, 47(1), 90-100.

18. Albert, A., \& Anderson, J. A. (1984). On the existence of maximum likelihood estimates in logistic regression models. Biometrika, 71(1), 1-10.

19. Oh, J. C., Yoon, S. J., \& Park, B. I. (2012). A structural approach to examine the quality attributes of e- shopping malls using the Kano model. Asia Pacific Journal of Marketing and Logistics.

20. Chen, M. C., Chang, K. C., Hsu, C. L., \& Yang, I. C. (2011). Understanding the relationship between service convenience and customer satisfaction in home delivery by Kano model. Asia Pacific Journal of Marketing and Logistics.

21. Chiang, T. L., Yi, C. Y., \& Chang, C. M. (2013, July). An empirical study of applying Kano model and TRIZ business evolution trends to improve Ecommerce service quality. In Proceedings of 2013 IEEE International Conference on Service Operations and Logistics, and Informatics (pp. 340344). IEEE.

22. Gliem, J. A., \& Gliem, R. R., editors. (2003). Calculating, interpreting, and reporting Cronbach's alpha reliability coefficient for Likert-type scales. 2003: Midwest Research-to-Practice Conference in Adult, Continuing, and Community ....

23. Allen, I. E., \& Seaman, C. A. (2007). Likert scales and data analyses. Quality progress, 40(7), 64-65.

24. Shevlin, M., Miles, J. N., \& Bunting, B. P. (1997). Summated rating scales. A Monte Carlo investigation of the effects of reliability and collinearity in regression models. Personality and Individual Differences, 23(4), 665-676.

25. Spector, P. E. (1992). Summated rating scale construction: An introduction (Vol. 82). Sage.

26. Santos, J. R. A. (1999). Cronbach's alpha: A tool for assessing the reliability of scales. Journal of extension, 37(2), 1-5.

27. Bland, J. M., \& Altman, D. G. (1997). Statistics notes: Cronbach's alpha. Bmj, 314(7080), 572.

28. Tavakol, M., \& Dennick, R. (2011). Making sense of Cronbach's alpha. International journal of medical education, 2, 53.

29. Raat, H., Botterweck, A. M., Landgraf, J. M., Hoogeveen, W. C., \& Essink-Bot, M. L. (2005). Reliability and validity of the short form of the child health questionnaire for parents (CHQ-PF28) in large random school based and general population samples. Journal of Epidemiology \& Community Health, 59(1), 75-82.

30. Sauerwein, E., Bailom, F., Matzler, K., \& Hinterhuber, H. H., editors. (1996). The Kano model: How to delight your customers. International Working Seminar on Production Economics.

31. Matzler, K., Hinterhuber, H. H., Bailom, F., \& Sauerwein, E. (1996). How to delight your customers. Journal of Product \& Brand Management.

32. Yoon, H. S., \& Occeña, L. G. (2015). Influencing factors of trust in consumer-to-consumer electronic commerce with gender and age. International journal of information management, 35(3), 352363.

33. Chen, S. C., \& Dhillon, G. S. (2003). Interpreting dimensions of consumer trust in ecommerce. Information technology and management, 4(2-3), 303-318. 